\title{
A Rapid, Sensitive Assay for Ralstonia solanacearum Race 3 Biovar 2 in Plant and Soil Samples Using Magnetic Beads and Real-Time PCR
}

Youngsil Ha, Department of Plant Pathology, Joo-Sung Kim, Department of Microbiology, Timothy P. Denny, Department of Plant Pathology, and Mark A. Schell, Departments of Plant Pathology and Microbiology, The University of Georgia, Athens 30602

\begin{abstract}
Ha, Y., Kim, J.-S., Denny, T. P., and Schell, M. A. 2012. A rapid, sensitive assay for Ralstonia solanacearum race 3 biovar 2 in plant and soil samples using magnetic beads and real-time PCR. Plant Dis. 96:258-264.

The Ralstonia solanacearum species complex causes economically significant diseases in many plant families worldwide. Although generally limited to the tropics and subtropics, strains designated race 3 biovar 2 (R3Bv2) cause disease in cooler tropical highlands and temperate regions. R3Bv2 has not become established in North America but, due to concerns that it could devastate the U.S. potato industry, it has been designated a Select Agent, and is subject to strict quarantine regulations. Quarantine screening for $\mathrm{R} 3 \mathrm{Bv} 2$ requires rapid and robust assays applicable to small populations present in plant tissues or soil, and must distinguish R3Bv2 from the multiple other $R$. solanacearum subgroups. We developed a $100 \%$-accurate real-time polymerase chain

reaction (RT-PCR) assay that can detect $\mathrm{R} 3 \mathrm{Bv} 2$ populations $>1,000$ cells $\mathrm{ml}^{-1}$. However, detection by RT-PCR was inhibited by compounds present in some plant and soil samples. Therefore, we developed simple immunomagnetic separation (IMS) and magnetic capture hybridization $(\mathrm{MCH})$ methods to purify $R$. solanacearum cells or DNA from PCR inhibitors. When coupled with RT-PCR, these tools permitted detection of R3Bv2 at levels $>500$ cells $\mathrm{ml}^{-1}$ in stem, tuber, and soil samples when direct RT-PCR failed, and reduced detection time from days to hours. IMS-RT-PCR was usually more sensitive than MCH-RTPCR, especially at lower population levels.
\end{abstract}

Ralstonia solanacearum causes bacterial wilt or brown rot disease of many plants in over 50 different families $(9,22)$. This pathogen is endemic in most tropical and subtropical regions, and its diseases often result in severe losses in a variety of commercial and subsistence crops. There is extensive genetic diversity among strains and, based on multilocus DNA sequence typing, $R$. solanacearum is now considered to be a species complex divided into four groups called phylotypes, which are subdivided into sequevars based on the DNA sequence of the egl endoglucanase gene $(5,19,56)$. Historically, however, $R$. solanacearum strains have been classified into five races based loosely on host range or into six biovars based on their differential ability to produce acid from several carbohydrate substrates (9). There is no general correlation between races and biovars, except that race 3 and race 5 strains are usually biovars 2 and 5, respectively.

Race 3 biovar 2 (R3Bv2) strains have an unusual ability to cause wilt disease at cooler temperatures than other $R$. solanacearum strains $(9,13,22,37,53)$. They can also survive in latent infections of potato tubers and other plants $(9,22)$. These traits and seed potato commerce have contributed to the dissemination of R3Bv2 strains to most potato-growing regions of the world, including tropical highlands and northern Europe (14). Outbreaks in Europe have significantly damaged seed potato production and resulted in quarantine-related crop losses $(27,28)$. Latent infections of geraniums with R3Bv2 in some parts of Africa and Central America have been a problem for commercial production of this exported crop

\section{Corresponding author: T. P. Denny, E-mail: tdenny@uga.edu}

Current address of Y. Ha: IEH Laboratories \& Consulting Group, Lake Forest Park, WA 98155.

Current address of J.-S. Kim: Korea Food Research Institute, 516 Baekhyun-Dong, Bundang-Ku, Sungnam-Si, Gyeonggi-Do 463-746, South Korea.

Accepted for publication 24 September 2011.

http://dx.doi.org/10.1094/PDIS-05-11-0426

(C) 2012 The American Phytopathological Society
$(28,61)$. Once R3Bv2 is introduced into a cropping system, it is difficult to manage because (i) host resistance is limited, (ii) it can survive long-term in weeds and soil, and (iii) it can be further disseminated via latently infected plant tissues or tubers, irrigation water, and soil-contaminated equipment $(6,9,24)$.

$\mathrm{R} 3 \mathrm{Bv} 2$ is not established in North America but, due to concerns that it threatens potato in the United States and Canada, it is designated as a Select Agent and subject to strict quarantine and biosecurity regulations $(6,32)$. These regulations identify the pathogen as R3Bv2 (rather than describing it as phylotype II, sequevar 1); therefore, we will do likewise in this article. Preventing introduction of R3Bv2 into North America requires rapid, robust, and reliable detection of this pathogen when it is present in relatively low numbers in asymptomatic tissues or in associated soil or debris. However, as with many pathogens, the methods presently available for specifically detecting R3Bv2 strains are inadequate. For example, conventional identification techniques, which often require isolation in pure culture, are laborious and time consuming. Several semiselective media are available for $R$. solanacearum but growth of competing or antagonistic organisms from soil can prevent its recovery, especially when it is present in low numbers (45). Even when $R$. solanacearum has been recovered from plant tissue or soil, additional cultural, biochemical, or genetic tests are required to determine if a strain is R3Bv2 $(10,37,39,63)$. Although relatively simple, the entire process can take several weeks.

Testing plant tissue or soil extracts for a pathogen directly using immunological or DNA-based techniques is considerably more rapid, usually requiring less than 1 day. A number of immunodiagnostic assays, including enzyme-linked immunosorbent assay (ELISA), immunofluorescence-antibody staining, immunofluorescence-colony staining, and commercial serological kits, have been developed to detect and identify $R$. solanacearum (9). Although these techniques can display detection thresholds as low as $10^{4}$ cells $\mathrm{g}^{-1}$ or $\mathrm{ml}^{-1}$ of sample, the presently available $R$. solanacearum-specific antibodies cannot differentiate between R3Bv2 and other $R$. solanacearum strains (9). Diagnostic polymerase chain reaction (PCR) assays, which are rapid and sensitive, have been successfully employed in the medical, veterinary, agricultural, and food-testing arenas (16). Species-, phylotype- and biovar-specific primers for $R$. solanacearum have been developed for conventional 
and real-time (RT)-PCR $(3,4,8,18,19,25,31,39,41,51,54,59)$. Unfortunately, conventional and RT-PCR reactions are often inhibited by excessive nontarget DNA, as well as by inhibitory compounds present in tissue or soil extracts $(40,43,47,62)$. Current attempts to reduce or eliminate these contaminants by dilution or neutralization of PCR inhibitors, isolation of target cells, or DNA purification can increase assay time and costs while reducing sensitivity $(23,43,44,59)$.

An alternative strategy is to adapt magnetic bead separation techniques to quickly, specifically, and easily purify cells or highquality DNA from contaminated soil and infected plant material. Immunomagnetic separation (IMS) uses magnetic beads coated with microbe-specific antibodies to isolate target bacteria free from PCR inhibitors before DNA is released for analysis. Alternatively, in magnetic capture hybridization $(\mathrm{MCH})$, beads coated with a microbe-specific single-stranded oligonucleotide are hybridized to total DNA released from a sample, and PCR inhibitors are washed away before purified target DNA is released. IMS and MCH followed by conventional or RT-PCR have been used to detect microorganisms in soil, food, plant tissue, and seed $(1,7,21,26,43,57)$. Here, we report development of IMS and $\mathrm{MCH}$ methods for R3Bv2 strains which, when coupled with RT-PCR, provide rapid and specific assays to detect low concentrations of this select agent and quarantine pathogen in complex plant tissue samples and soil.

\section{Materials and Methods}

Bacterial strains and culture conditions. $R$. solanacearum strains (Table 1) were cultured in BG broth or on BG agar (34) at $30^{\circ} \mathrm{C}$. Other bacteria-R. pickettii American Type Culture Collection (ATCC) 27511, R. pickettii $\mathrm{PH} 2$, Burkholderia thailandensis E264, Sinorhizobium meliloti 54, Pseudomonas putida ATCC 12633, R. eutropha JH16, B. cepacia J2315, Acinetobacter (calcoaceticus) baylii ADP1, P. aeruginosa PAO1, and Klebsiella (aerogenes) pneumoniae ATCC 9621-were cultured on LuriaBertani (LB) agar or in $\mathrm{LB}$ broth at $30^{\circ} \mathrm{C}$. R. solanacearum extracellular polysaccharide-deficient (EPS-) strain IPO1609 EPSwas generated by transformation (34) using genomic DNA purified from strain UW551 EPS-.

Preparation of antisera. The R3Bv2 $R$. solanacearum strains UW24, UW551, UW349, IPO1609, and UW551 EPS- were grown for $36 \mathrm{~h}$ with agitation. Cells were harvested by centrifugation and resuspended in water to an optical density at $600 \mathrm{~nm}\left(\mathrm{OD}_{600}\right)$ of 10 . Equal volumes of each suspension were combined, heated to $55^{\circ} \mathrm{C}$ for $40 \mathrm{~min}$, and then diluted with water to $2.5 \mathrm{mg} \mathrm{ml}^{-1}$ of cell protein. A $0.5-\mathrm{ml}$ aliquot was emulsified with an equal volume of Freund's complete adjuvant and the mixture was injected intradermally at multiple sites into an adult NZW-SPF rabbit by personnel at The University of Georgia University Research Animal Resources lab (http://www.ovpr.uga.edu/urar/ls/). Four weeks later, the rabbit was injected with the same volume of cell mixture that had been emulsified with incomplete Freund's adjuvant. Blood was harvested 10 days later, and the serum prepared from it was frozen.

Dot-blot assays of antisera. Strains were grown to an $\mathrm{OD}_{600}$ of approximately 1 and $2 \mu \mathrm{l}$ of each culture, or dilutions thereof, were spotted onto nitrocellulose membranes. In some cases, $1 \mathrm{ml}$ of a culture was centrifuged at $7,000 \times g$ for $1 \mathrm{~min}$ and the cell pellets resuspended in 0.05 volume of water before spotting. After air drying, the membranes were blocked by shaking overnight at $25^{\circ} \mathrm{C}$ in $50 \mathrm{mM}$ Tris- $\mathrm{HCl}(\mathrm{pH} \mathrm{7.6)}+0.15 \mathrm{M} \mathrm{NaCl}+0.1 \%$ Tween $20+$ $2 \%$ Difco skim milk (TBSTS) and then shaken at $25^{\circ} \mathrm{C}$ with a 1:10,000 dilution of polyclonal antiserum in TBSTS for $1 \mathrm{~h}$. After washing with TBSTS for $10 \mathrm{~min}$, membranes were shaken with a 1:10,000 dilution of horseradish peroxidase-conjugated goat antirabbit antibody (Bio-Rad, Hercules, CA) in TBSTS for $1 \mathrm{~h}$ and then washed with TBSTS as described above. The membranes were rinsed with water; then, ready-to-use, stabilized 3,3',5,5'tetramethylbenzidine substrate (TMB; Promega Corp., Madison, WI) was added. After 10 min of shaking, the membrane was rinsed with water to stop the color development, air dried, and photographed.

Preparation of anti- $R$. solanacearum magnetic beads. Dynabeads sheep anti-rabbit immunoglobulin $\mathrm{G}$ ( $\mathrm{IgG}$ )-coated magnetic beads ( $1 \mathrm{ml}$, approximately $10^{9}$ beads; Invitrogen, Carlsbad, CA) were transferred to a 2-ml cylindrical microfuge tube (Axygen Inc., Union City, CA; catalog number MCT-200-C). The tube was placed in a magnetic particle collector (MPC; Promega Corp.; catalog number Z5333) for 2 min while the beads became immobilized on the rear wall of the tube. Supernatant was carefully removed while the tube remained in the MPC. The beads were washed by adding $1 \mathrm{ml}$ of phosphate-buffered saline (PBS; 140 $\mathrm{mM} \mathrm{NaCl}, 3 \mathrm{mM} \mathrm{KCl}, 8 \mathrm{mM} \mathrm{Na} 2 \mathrm{HPO}_{4}$, and $2 \mathrm{mM} \mathrm{KH}_{2} \mathrm{PO}_{4}, \mathrm{pH}$ 7.4) containing $0.5 \%$ bovine serum albumin (PBSB) along the wall where the beads were bound and, after $1 \mathrm{~min}$, carefully removing the PBSB. The washed beads were then mixed with $300 \mathrm{mg}$ of $\mathrm{IgG}$ that had been purified from anti- $R$. solanacearum rabbit serum using a Protein A Antibody Purification Kit (Sigma-Aldrich, St. Louis). After shaking for $18 \mathrm{~h}$ at $7^{\circ} \mathrm{C}$, the beads were washed twice with $1 \mathrm{ml}$ of PBS using an MPC as described above, and stored at $4^{\circ} \mathrm{C}$ in $\mathrm{PBS}+0.02 \% \mathrm{NaN}_{3}$.

Preparation of MCH beads. Dynabeads M-280 Streptavidin magnetic beads ( $1 \mathrm{ml}$, approximately $10^{9}$ beads; Invitrogen) were washed three times with $1 \mathrm{ml}$ of $2 \times$ bead wash buffer (BW; $10 \mathrm{mM}$ Tris-HCl [pH 7.5], $1 \mathrm{mM}$ EDTA, and 2.0 M NaCl) using an MPC as described above. The beads were mixed with $1 \mathrm{ml}$ of BW containing 200 pmol of 2403CAPYH capture oligonucleotide (5' biotin-ATCCTTTGTGCTGAAGGCCGTTATCGGCCTTGCAGGC CCGCAAGGTGGGATGGATGTGTT-3'; targets between 65 and 5 bp upstream of the R3Bv2 diagnostic amplicon). After shaking for $1 \mathrm{~h}$ at $25^{\circ} \mathrm{C}$, tubes were placed in the MPC and beads were washed three times with $1 \mathrm{ml}$ of BW. The beads were suspended in $0.4 \mathrm{ml}$ of $0.125 \mathrm{M} \mathrm{NaOH}$ plus $0.5 \mathrm{M} \mathrm{NaCl}$, incubated at $25^{\circ} \mathrm{C}$ for $15 \mathrm{~min}$, rinsed three times with $1 \mathrm{ml}$ of $\mathrm{BW}$, and stored at $4^{\circ} \mathrm{C}$ in $0.15 \mathrm{ml}$ of $\mathrm{BW}+0.02 \% \mathrm{NaN}_{3}$.

IMS procedure. Fivefold concentrated PBSB $(0.2 \mathrm{ml})$ was added to $0.8-\mathrm{ml}$ test samples in 2-ml cylindrical microfuge tubes and $7 \mu \mathrm{l}$ (approximately $5 \times 10^{9}$ beads) of anti- $R$. solanacearum magnetic beads was added. The tubes were manually inverted two or three times every $15 \mathrm{~min}$ at $25^{\circ} \mathrm{C}$ for $60 \mathrm{~min}$ and then placed in the MPC. After $2 \mathrm{~min}$, the supernatant was carefully removed, leaving the beads immobilized on the rear wall of the tubes undisturbed, and then $2 \mathrm{ml}$ of PBSB was added and removed after approximately $30 \mathrm{~s}$. Beads were then similarly washed with $1 \mathrm{ml}$ of PBS followed by $1 \mathrm{ml}$ of sterile water. Finally, after the tubes were removed from the MPC, $1 \mathrm{ml}$ of sterile water was added, beads

Table 1. Ralstonia solanacearum strains used

\begin{tabular}{lll}
\hline Strain & \multicolumn{1}{c}{ Relevant characteristics } & Reference or source \\
\hline AW1 & Race 1 biovar 1 (phylotype II sequevar 7) & 11 \\
GMI1000 & Race 1 biovar 3 (phylotype I sequevar 18) & 49 \\
GMI1000 EPS- & GMI1000 eps B::pCR2.1, EPS- & M. A. Schell and J. Wang, unpublished \\
UW551 & Race 3 biovar 2 (phylotype II sequevar 1) & 20 \\
UW551 EPS- & UW551 epsB::pVIK112, EPS- & 36 \\
IPO1609 & Race 3 biovar 2 (phylotype II sequevar 1) & 55 \\
IPO1609 EPS- & IPO1609 epsB::pVIK112, EPS- & This study \\
UW24 & Race 3 biovar 2 (phylotype II) & C. Allen, University of Wisconsin \\
UW349 & Race 3 biovar 2 (phylotype II) & C. Allen, University of Wisconsin \\
\hline
\end{tabular}


were resuspended by pipetting, and the suspension was transferred to a $1.5-\mathrm{ml}$ conical centrifuge tube. After placing this tube in the MPC for $2 \mathrm{~min}$, the supernatant was carefully removed and $30 \mu \mathrm{l}$ of water was added. The tube was removed from the MPC and centrifuged for $5 \mathrm{~s}$ to force all beads and liquid to the bottom. After resuspension by pipetting, appropriate aliquots of the bead suspension, or dilutions thereof, were spread plated on BG agar and colonies were counted after 2 days. The remaining portion of the bead suspension was heated at $97^{\circ} \mathrm{C}$ for $7 \mathrm{~min}$ and centrifuged for $30 \mathrm{~s}$, and the bead-free supernatant was saved for RT-PCR. IMS assays involving geranium or soil extracts required more extensive washing to remove PCR inhibitors: once with $2 \mathrm{ml}$ of PBSB, three times with $1 \mathrm{ml}$ of PBS, and twice with $1 \mathrm{ml}$ of sterile water before transfer to a new tube for heat elution of DNA.

MCH procedure. Tris-EDTA buffer $(0.1 \mathrm{ml} ; 10 \mathrm{mM}$ Tris- $\mathrm{HCl}$ [pH 8.0] plus $1 \mathrm{mM}$ EDTA) was added to $0.4-\mathrm{ml}$ test samples in 2$\mathrm{ml}$ cylindrical tubes. After heating at $95^{\circ} \mathrm{C}$ for $5 \mathrm{~min}, 0.4 \mathrm{ml}$ of DIG Easy Hyb solution (Hoffmann-La Roche, Inc., Nutley, NJ) was added. After incubation at $95^{\circ} \mathrm{C}$ for $10 \mathrm{~min}$, samples were chilled on ice for $5 \mathrm{~min}$, and $20 \mu \mathrm{l}$ (approximately $10^{8}$ beads) of 2403CAPYH magnetic beads was added. After shaking at $25^{\circ} \mathrm{C}$ for $2 \mathrm{~h}$, tubes were placed in an MPC for $2 \mathrm{~min}$, the supernatant was removed, and the beads were washed once with $2 \mathrm{ml}$ of water, followed by two more washes with $1 \mathrm{ml}$ of water as described for IMS above. Finally, beads were suspended in $20 \mu \mathrm{l}$ of water, incubated at $95^{\circ} \mathrm{C}$ for $10 \mathrm{~min}$, and centrifuged for $5 \mathrm{~s}$, and the supernatant was removed and saved for RT-PCR. MCH assays involving geranium or soil extracts also required more extensive washing: once with $2 \mathrm{ml}$ of water followed by five washes with $1 \mathrm{ml}$ of water.

RT-PCR. Design and characterization of R3Bv2-specific PCR primers targeting the RRSL_2403 gene were previously described (31). RT-PCR was performed using either iQ SYBR Green Supermix (Bio-Rad) or SYBR Green PCR Master Mix (Applied Biosystems, Life Technologies Inc., Carlsbad, CA) with the Smart Cycler II (Cepheid, Sunnyvale, CA) or StepOne (Applied Biosystems) instruments, respectively. The $25-\mu \mathrm{l}$ reactions containing $12.5 \mu \mathrm{l}$ of master mix, 10 pmol each primer (RRSL2403F/R), and $5 \mu$ of test sample were incubated at $95^{\circ} \mathrm{C}$ for $10 \mathrm{~min}$, followed by 40 cycles of $95^{\circ} \mathrm{C}$ for $15 \mathrm{~s}, 58^{\circ} \mathrm{C}$ for $15 \mathrm{~s}$, and $72^{\circ} \mathrm{C}$ for $30 \mathrm{~s}$. The detection threshold of the StepOne system was set automatically whereas, for the Smart Cycler II, it was set to 15 fluorescence units. The cycle threshold $(\mathrm{Ct})$ value was determined as the RT-PCR cycle at which fluorescence exceeded the detection threshold.

\begin{tabular}{|c|c|c|c|c|c|c|c|}
\hline \multirow[b]{2}{*}{$\underline{\text { Strain }}$} & \multicolumn{7}{|c|}{ Number of cells applied } \\
\hline & $10^{6}$ & $10^{5}$ & $10^{4}$ & & $10^{7}$ & & $10^{7}$ \\
\hline GM & - & 6 & & Bt & & Kp & \\
\hline Gm EPS- & (a) & (2) & & Sm & & $\operatorname{Re}$ & O \\
\hline 551 & & (1) & O & $\mathrm{Pp}$ & & $\mathrm{Bc}$ & 0 \\
\hline 551 EPS- & & (1) & 8 & $A b$ & & $\mathrm{Rp} 2$ & ○ \\
\hline Rp1 & - & (9) & & Rp1 & 0 & $\mathrm{~Pa}$ & \\
\hline
\end{tabular}

Fig. 1. Specificity and detection sensitivity of rabbit antiserum against Ralstonia solanacearum. Serial dilutions of cells were spotted on to a nitrocellulose membrane. After drying and blocking and incubation with anti- $R$. solanacearum antibodies, membranes were developed with horseradish peroxidase-conjugated goat anti-rabbit immunoglobulin $G$ and TMB substrate. $R$. solanacearum strains: GM, GMl1000; 551, UW551; EPS-, deficient in exopolysaccharide production. Other bacteria: Rp1, R. pickettii ATCC 27511; Rp2, R. pickettii PH2; Bt, Burkholderia thailandensis; Sm, Sinorhizobium meliloti; Pp, Pseudomonas putida; Re, R. eutropha; Bc, B. cepacia; Ab, Acinetobacter (calcoaceticus) baylii; $\mathrm{Pa}, P$. aeruginosa; Kp, Klebsiella (aerogenes) pneumoniae.
Preparation of plant tissue and soil extracts. For potato tubers, a number 5 cork borer was used to obtain a 0.8 -by-2-cm cylindrical tissue sample. After removing the skin, the cylinder was cut into approximately 10 slices and $1 \mathrm{~g}$ was added to $10 \mathrm{ml}$ of water in a 15-ml Falcon tube (BD Biosciences, Bedford, MA). After vortexing for $15 \mathrm{~s}$, tubes were inverted by hand five times every $5 \mathrm{~min}$ for $15 \mathrm{~min}$. Insoluble debris was allowed to settle for 15 min and the supernatant was removed. For stems, an approximately $2-\mathrm{cm}$ stem segment weighing approximately $1 \mathrm{~g}$ was cut from the center of the plant, placed in a 15-ml Falcon tube, and crushed with the tip of a $5-\mathrm{ml}$ plastic pipette, and $10 \mathrm{ml}$ of water was added. The tube was vortexed vigorously and further processed as described for potato tubers. For soil, $1 \mathrm{~g}$ of soil (sandy loam with $5.9 \%$ organic matter, $\mathrm{pH}$ 6.6) was suspended in $10 \mathrm{ml}$ of water and processed as described for stem samples. The amount of dissolved solids in each extract was determined gravimetrically and found to be $1.0 \mathrm{mg} \mathrm{ml}^{-1}$ for tubers, $3.5 \mathrm{mg} \mathrm{ml}^{-1}$ for plant stems, and $0.3 \mathrm{mg} \mathrm{ml}^{-1}$ for soil.

\section{Results}

Characterization of titer and specificity of anti- $R$. solanacearum serum. Efficient IMS requires a high-titer and high-affinity antibody. Because several attempts to generate an R3Bv2-specific monoclonal antibody were unsuccessful (G. D. Peckham and A. M. Alvarez, unpublished), we prepared polyclonal antiserum against a mixture of five R3Bv2 strains, one of which is deficient in EPS production. Ability of the antisera to strongly react with EPSstrains was considered critical because EPS is produced at very low levels, if at all, when $R$. solanacearum is growing at low cell density $(29,50)$. Of three available $R$. solanacearum-specific monoclonal antibodies we tested, none reacted with EPS- strains (unpublished data). At a 1:10,000 dilution, our antiserum reacted strongly with cells of both $R$. solanacearum GMI1000 (race 1, biovar 3), and UW551 (R3Bv2), as well as their EPS- mutants (GMI1000 EPS- and UW551 EPS-, respectively) (Fig. 1). This antiserum also reacted strongly with $R$. pickettii cells. The other species of Burkholderiaceae that were tested reacted weakly $(R$. eutropha and B. cepacia) or not at all (B. thailandensis), while six other $\alpha$ - and -proteobacteria did not react. In the dot-blot assay, this antiserum detected as few as $10^{4}$ cells of $R$. solanacearum (Fig. 1) and, at a 1:200 dilution, it detected $10^{3}$ cells (results not shown).

Prominent antibody-reactive haloes surrounded the spots with $10^{6}$ cells of wild-type $R$. solanacearum strains GMI1000 and UW551 but the haloes were dramatically reduced in size and color intensity for their EPS- mutants (Fig. 1). Haloes also were essentially absent when wild-type cells were washed three times with water before spotting on the membrane (not shown). Haloes were present when the $0.45-\mu \mathrm{m}$ filtered cell-free culture supernatant from EPS-producing cells but not EPS- cells was applied to the membrane (not shown). These results suggested that the anti-R. solanacearum polyclonal antibodies bound not only to cells but also to cell-free EPS.

Specificity and sensitivity of IMS for $R$. solanacearum. Anti$R$. solanacearum magnetic beads were prepared by conjugation with IgG purified from the polyclonal serum. When employed in an IMS procedure, the beads were more specific and sensitive in detecting a variety of $R$. solanacearum strains than the dot blot method (Table 2). On average, the IMS beads recovered $22 \%$ of the approximately $10^{5} R$. solanacearum cells in the $1-\mathrm{ml}$ reaction but, in contrast to the dot blot assay, $R$. pickettii or B. cepacia cells were not detected. This was not surprising, because the spots on the dot blot contained dried cells that likely had released cytoplasmic antigens for reaction with the antiserum, whereas the anti- $R$. solanacearum magnetic beads only reacted with antigens on the surface of intact cells. R. eutropha, one of the strains that was weakly positive in dot blot analysis, was also recovered by IMS but at levels nearly 100 -fold less than the $R$. solanacearum strains. Nonspecific binding of $R$. solanacearum cells to unconjugated beads was negligible. The recovery of EPS- cells was consistently 
three- to fivefold less than for EPS-producing wild-type cells, again indicating that EPS is a major recognition determinant and that its presence enhances detection of $R$. solanacearum cells. Tests to determine the recovery efficiency of $R$. solanacearum from IMS reactions with decreasing concentrations of cells showed that this technique worked with as few as 10 cells $\mathrm{ml}^{-1}$ (Table 3 ). These results show that the IMS beads provide a consistent, robust, and accurate detection method for $R$. solanacearum cells.

Coupling IMS to RT-PCR increased speed and sensitivity of detecting $\boldsymbol{R}$. solanacearum. Although the IMS procedure is fairly rapid (approximately $2 \mathrm{~h}$ ), obtaining final results from plate counts takes about 2 days. More importantly, IMS does not differentiate between races or biovars of $R$. solanacearum. An R3Bv2-specific PCR primer set targeting the RRSL_2403 gene of strain UW551 was previously been reported (31). An RT-PCR assay using these primers detected as few as five R3Bv2 cells (using $5 \mu \mathrm{l}$ of a $10^{3}$ $\mathrm{CFU} \mathrm{ml}{ }^{-1}$ suspension) in $2 \mathrm{~h}$ (Table 4 ), which was nearly as sensitive as plating and approximately 25 times faster. Therefore, we evaluated coupling IMS to R3Bv2-specific RT-PCR to enhance both sensitivity (e.g., by concentrating cells from $1 \mathrm{ml}$ to $30 \mu \mathrm{l}$ ) and speed. When we subjected a $200 \mathrm{CFU} \mathrm{m}{ }^{-1} \mathrm{R} 3 \mathrm{Bv} 2$ cell suspension to IMS and assayed one-half of the eluted sample by RT-PCR, we obtained a $\mathrm{Ct}$ value of 31 , whereas the other half of the sample contained approximately 12 cells, as determined by plate counts. Not surprisingly, direct RT-PCR assay of the $200 \mathrm{CFU} \mathrm{m}{ }^{-1} \mathrm{R} 3 \mathrm{Bv} 2$ cell suspension did not give a $\mathrm{Ct}$ value, because the 5- $\mu \mathrm{l}$ aliquot used in RT-PCR would have contained less than one cell. Thus, by concentrating $R$. solanacearum cells, IMS increased sensitivity for R3Bv2 detection by RT-PCR 8- to 64-fold, depending on the target population size. The process also reduced detection time approximately 10-fold.

MCH coupled to RT-PCR also increased speed and sensitivity of detecting $\boldsymbol{R}$. solanacearum. Antiserum for use in IMS is not always readily available and can be difficult or costly to prepare. As an alternative, $\mathrm{MCH}$ using a bacterium- or strain-specific oligonucleotide (the capture probe) coupled to magnetic beads can be used to capture, via hybridization, a diagnostic DNA sequence that can be detected by RT-PCR. We coupled a 60-bp oligonucleotide (complementary to an RRSL_2403 sequence adjacent to the R3Bv2-diagnostic amplicon) to magnetic beads. When used in an $\mathrm{MCH}$ procedure, these beads consistently allowed RT-PCR detection of $R$. solanacearum $\mathrm{R} 3 \mathrm{Bv} 2$ at concentrations as low as $10^{3}$ $\mathrm{CFU} \mathrm{ml} \mathrm{m}^{-1}$, whereas direct RT-PCR detection at this concentration occurred only about half the time. Although $\mathrm{MCH}$ functioned nearly as well or better than IMS at cell concentrations $>10^{5} \mathrm{CFU}$

Table 2. Efficiency and specificity of immunomagnetic separation (IMS) for detection of Ralstonia solanacearum strains as determined by plate counts

\begin{tabular}{lc}
\hline Strain & Cells bound $^{\mathbf{a}}$ \\
\hline R. solanacearum UW551 & 23,500 \\
R. solanacearum IPO1609 & 42,000 \\
R. solanacearum GMI1000 & 32,000 \\
R. solanacearum AW1 & 11,500 \\
R. solanacearum IPO1609 EPS- & 8,400 \\
R. solanacearum UW551 EPS- & 12,000 \\
R. solanacearum GM1000 & 50 \\
R. eutropha JH16 & 1,500 \\
R. pickettii ATCC 27511 & ND \\
Sinorhizobium meliloti 54 & ND \\
Burkholderia cepacia J2315 & ND \\
\hline
\end{tabular}

${ }^{a}$ Cells were diluted in phosphate-buffered saline containing $0.5 \%$ bovine serum albumin (to $10^{5} \mathrm{CFU} \mathrm{ml}{ }^{-1}$ ) and 1 -ml aliquots were subject to IMS with anti-R. solanacearum immunoglobulin $\mathrm{G}(\mathrm{IgG})$-conjugated magnetic beads. Aliquots of thrice-washed beads were plated on BG agar to determine the number of bound cells. Values are average of two independent experiments with less than twofold variation and representative of more than three other determinations. $\mathrm{ND}=$ none detected: no colonies were observed after 5- $\mu \mathrm{l}$ aliquots of beads were plated.

${ }^{\mathrm{b}}$ Unconjugated goat anti-rabbit $\operatorname{IgG}$ beads were used instead of anti- $R$. solanacearum beads. $\mathrm{ml}^{-1}$ (Table 4), IMS showed better sensitivity at cell concentrations $<10^{5} \mathrm{CFU} \mathrm{ml} \mathrm{m}^{-1}$.

IMS and MCH allow rapid detection of cryptic populations of $\boldsymbol{R}$. solanacearum in field sample mimics. Detection of R3Bv2 in quarantine screening situations requires rapid and accurate analysis of tissues from plants such as potato, tomato, and geranium, and also soil and water samples. Such samples are extremely complex in molecular and cellular content, and inhibition of PCR by soil or plant materials is well documented $(2,64)$. Therefore, we set up a model system to evaluate the use of IMS and $\mathrm{MCH}$ to purify and concentrate R3Bv2 cells or DNA away from PCR inhibitors likely to be encountered in real-world test samples. Extracts of noninfected plant tissues or soil were prepared and R3Bv2 cells added to simulate complex positive samples. In preliminary experiments, we found that detection of R3Bv2 by RT-PCR was blocked if simulation mixtures contained $>2 \%$ of extracts of potato stem, potato tuber, geranium stem, or soil unless the concentration of R3Bv2 cells exceeded $10^{6} \mathrm{CFU} \mathrm{m}{ }^{-1}$. At $5 \%$, all extracts except those from tomato stems completely blocked RT-PCR detection, even at $10^{7} \mathrm{CFU} \mathrm{ml^{-1 }}$. In general, only when the ratio of cells to extract exceeded $10^{7}$ cells $\mathrm{g}^{-1}$ for potato tuber or stem extract or $10^{8}$ cells $\mathrm{g}^{-1}$ for soil or geranium stem extracts could detection by direct RT-PCR be assured. In contrast, when positive field sample mimics with extract concentrations of 3 to $7 \%$ and cell concentrations of $10^{6}$ to $10^{3} \mathrm{CFU}$ of R3Bv2 $\mathrm{ml}^{-1}$ were subjected to IMS or $\mathrm{MCH}$ and then analyzed by RT-PCR, R3Bv2 cells were detected in most of the samples whereas direct detection by RT-PCR failed (Table 5). The $\mathrm{Ct}$ values obtained from IMS-coupled RT-PCR for samples with $10^{3} \mathrm{CFU} \mathrm{ml}{ }^{-1}$ suggested that R3Bv2 could be reliably and unambiguously detected by our method well below this concentration in extracts of both potato stem and tuber and, likewise, well below the $10^{4} \mathrm{CFU} \mathrm{ml}{ }^{-1}$ level in soil and geranium ex-

Table 3. Sensitivity of immunomagnetic separation (IMS) for detection of Ralstonia solanacearum

\begin{tabular}{lc}
\hline Initial cell number $^{\mathbf{a}}$ & Cells bound (recovery [\%]) \\
\hline $10^{5}$ & $35,000(35)$ \\
$10^{4}$ & $3,900(39)$ \\
$10^{3}$ & $170(17)$ \\
$10^{2}$ & $18(18)$ \\
$10^{1}$ & $3(30)$ \\
\hline
\end{tabular}

a IMS was performed on 1-ml reactions containing the indicated number of GMI1000 cells as described for Table 2. Number of cells bound to beads was determined by plate counts and are the average of more than four independent tests with less than twofold variation. IMS reactions using unconjugated goat anti-rabbit immunoglobulin $\mathrm{G}$ beads instead of anti- $R$. solanacearum beads resulted in a recovery of $<0.01 \%$.

Table 4. Comparison of immunomagnetic separation (IMS) and magnetic capture hybridization $(\mathrm{MCH})$ coupled with real-time polymerase chain reaction (RT-PCR) for detection of Ralstonia solanacearum R3Bv2

\begin{tabular}{|c|c|c|c|}
\hline \multirow[b]{2}{*}{ Conc. $\left(\mathrm{CFU} \mathrm{ml} \mathrm{ml}^{-1}\right)^{\mathbf{a}}$} & \multicolumn{3}{|c|}{ Cycle threshold $(\mathrm{Ct})$ value } \\
\hline & Direct PCR & IMS-RT-PCR & MCH-RT-PCR \\
\hline$\overline{10^{6}}$ & 21.2 & 22 & 20.3 \\
\hline $10^{5}$ & 26.1 & 22.9 & 24.4 \\
\hline $10^{4}$ & 30.5 & 24.6 & 27.7 \\
\hline $10^{3}$ & 32.3 & 26.7 & 31.2 \\
\hline 200 & $>33$ & 31 & 33 \\
\hline
\end{tabular}

${ }^{a}$ Cell concentration. $R$. solanacearum UW551 cells were diluted to the indicated concentrations in phosphate-buffered saline containing $0.5 \%$ bovine serum albumin for IMS and in water for $\mathrm{MCH}$; magnetic bead separations were carried out as described in Materials and Methods. For $\mathrm{MCH}$, samples were adjusted to $0.2 \times$ Tris-EDTA and heated at $97^{\circ} \mathrm{C}$ for 7 min before beads were added. Ct values were determined using $5 \mu \mathrm{l}$ of DNA eluted from beads and are the average of more than three independent experiments; $\mathrm{Ct}$ values varied by no more than $5 \%$ between experiments. Ct values $>33$ cycles were not considered reliable indicators of the presence of R3Bv2 cells or DNA because Ct values of 34 to 38 were sometimes obtained with samples lacking cells or DNA. 
tracts. Therefore, IMS and, to a lesser degree, $\mathrm{MCH}$ are simple and highly effective methods to dramatically increase the sensitivity of RT-PCR detection of R3Bv2 in field-sample mimics. In some cases, they were indispensible, because direct PCR was not possible.

\section{Discussion}

We developed two magnetic-bead-based assays to facilitate specific and sensitive detection of R3Bv2 in less than $4 \mathrm{~h}$ from samples that mimic the conditions expected to be present in field samples. Beads conjugated to $R$. solanacearum-specific antibodies or an R3Bv2-specific DNA capture oligonucleotide purified target cells or DNA away from PCR inhibitors so that the subsequent RTPCR routinely detected R3Bv2 at population levels as low as 500 $\mathrm{CFU} \mathrm{ml} \mathrm{m}^{-1}$. A number of methods have been previously used as pretreatments to reduce the level of PCR inhibitors and excess nontarget DNA in field samples $(30,33,35,38,42,60,62)$. Diluting samples 10- to 100-fold can increase success of subsequent detection by PCR (44) but this also dilutes the target cells, thereby reducing sensitivity and, thus, is unsuitable for samples with low target cell populations, such as latently infected tissues or soil. Swanson et al. (52) used $2 \mu \mathrm{m}$ - and $0.4 \mu \mathrm{m}$-filtration to concentrate target cells, as well as to remove inhibitors from the irrigation effluent of pots containing infected geranium plants; however, subsequent RT-PCR did not reliably detect R3Bv2 when populations were less than $10^{5}$ cells $\mathrm{ml}^{-1}$. Alternatively, DNA can be extracted directly from soil or plants and partially purified with a variety of methods to enhance detection by PCR $(4,8,25,43$, $45,47,51)$. However, these methods do not guarantee removal of inhibitors and, because they are time consuming and can use hazardous reagents or expensive kits, they are not suitable for routine diagnostic or detection procedures.

The most successful strategy to remove PCR inhibitors or enhance detection sensitivity has been to incubate the sample in a semiselective medium prior to PCR analysis $(40,60)$. Because such enrichment dramatically increases the target cells present in complex samples, and also greatly reduces the relative concentration of PCR inhibitors, this simple approach can be used with currently available immunological methods or PCR $(15,46,60)$. Unfortunately, this approach adds 24 to $96 \mathrm{~h}$ of incubation time and, especially in the case of soil samples, involves a risk that other bacteria will also multiply enough to interfere with PCR and increase the chance of contamination $(4,45,60)$.

The use of paramagnetic beads is a relatively simple and rapid way to partially purify targets and eliminate contaminants (26). In addition, concentration of the captured targets into a smaller volume enhances detection without time-consuming enrichment culture. Both our IMS and MCH effectively removed PCR inhibitors and permitted detection of $\mathrm{R} 3 \mathrm{Bv} 2$ down to 1,000 cells $\mathrm{ml}^{-1}$ in extracts of various plant tissues and soil that otherwise inhibited PCR. However, the inhibitory potency of each extract varied and, in part, depended on a sample's origin and the concentration of dissolved solids. As expected $(47,58,62)$, we found that extracts of soil were $>25$ times more potent in blocking PCR than those prepared from a potato stem or tuber, while similarly prepared tomato stem extracts were not inhibitory. Surprisingly, extracts of geranium stem were the most potent at inhibiting PCR. When testing for R3Bv2 in extracts with potent inhibitors, we found that it was critical to increase the number of times that the magnetic beads and tube surfaces were washed to attain positive test results. Hence, the extent of washing to remove PCR inhibitors must be empirically determined for different types of samples.

Magnetic bead technologies are also amenable to field use, because the equipment needs are minimal. Field applicability and efficacy of our IMS and MCH methods were demonstrated by analysis of stem and rhizosphere soil samples from wilted tomato plants prepared on site in Arenal, Guatemala. Stem samples tested positive for R3Bv2 using either direct, IMS-, or MCH-coupled RTPCR, whereas rhizosphere soil samples tested R3Bv2-positive only after MCH (results not shown).

There are two earlier reports where IMS was used to enhance detection of $R$. solanacearum. Expert et al. (17) recovered up to approximately $15 \%$ of the $R$. solanacearum cells when present at $>10^{6}$ cells ml ${ }^{-1}$ in water or potato tuber macerates but they did not test samples with lower cell concentrations. Our IMS procedure, however, captured approximately $25 \%$ of the $R$. solanacearum cells in water suspensions at concentrations of $10^{1}$ to $10^{5}$ cells ml ${ }^{-1}$. Although IMS is excellent for capturing $R$. solanacearum cells, it currently cannot be used alone to detect R3Bv2, because R3Bv2specific polyclonal or monoclonal antibodies are not available. Dittapongpitch and Surat (12) reported that IMS followed by standard PCR had a detection threshold of approximately $10^{4} R$. solanacearum cells $\mathrm{ml}^{-1}$ in water but they were unable to detect cells in soil extracts containing $<10^{5}$ cells $\mathrm{g}^{-1}$. In contrast, our IMS removed PCR inhibitors and nontarget cells in various plant and soil extracts and permitted specific detection of $R$. solanacearum R3Bv2 by RT-PCR down to the level of 200 cells $\mathrm{ml}^{-1}$. Thus, in addition to being R3Bv2 specific, our IMS-coupled RT-PCR is at least 10 -fold more sensitive than previously used IMS procedures and other immunodiagnostic assays that do not involve enrichment culture or plating (such as indirect ELISA, double-antibody sandwich ELISA, immunofluorescence-colony staining, and dip sticks), which have detection thresholds of $10^{4}$ to $10^{5}$ cells $\mathrm{g}^{-1}$ or $\mathrm{ml}^{-1}$ $(9,15,48)$.

There are also two reports describing MCH coupled to PCR for detecting $R$. solanacearum. Expert et al. (17) used beads coated with a nonspecific DNA-binding compound followed by standard PCR with $R$. solanacearum-specific primers to detect $R$. solanacearum at as few as $10^{2}$ cells $\mathrm{ml}^{-1}$ in tomato stem and potato tuber extracts, whereas detection by direct PCR required $>10^{4}$ cells $\mathrm{ml}^{-1}$. Poussier et al. (43) compared the use of $\mathrm{MCH}$ beads coated

Table 5. Evaluation of immunomagnetic separation (IMS) and magnetic capture hybridization (MCH) for detection of Ralstonia solanacearum R3Bv2 cells in complex environmental samples

\begin{tabular}{|c|c|c|c|c|c|c|c|c|c|c|c|c|}
\hline \multirow[b]{3}{*}{ Conc. $\left(\mathrm{CFU} \mathrm{m \textrm {m } ^ { - 1 }}\right)^{\mathrm{b}}$} & \multicolumn{12}{|c|}{ Cycle threshold $(\mathrm{Ct})$ values $^{\mathrm{a}}$} \\
\hline & \multicolumn{3}{|c|}{ Potato tuber extract } & \multicolumn{3}{|c|}{ Potato stem extract } & \multicolumn{3}{|c|}{ Geranium stem extract } & \multicolumn{3}{|c|}{ Soil extract } \\
\hline & IMS & МCH & PCR & IMS & MCH & PCR & IMS & МCH & PCR & IMS & МCH & PCR \\
\hline $10^{6}$ & 19.3 & 23 & $>33$ & 20.6 & 24.5 & $>33$ & 23.8 & 23.3 & $>33$ & 23.6 & 24.4 & $>33$ \\
\hline $10^{5}$ & 19.3 & 24.5 & $>33$ & 21 & 26.3 & $>33$ & 26.4 & 27.2 & $>33$ & 26.9 & 27.3 & $>33$ \\
\hline $10^{4}$ & 24 & 26.5 & $>33$ & 23.2 & 29 & $>33$ & 27.8 & 30 & $>33$ & 28.2 & 30 & $>33$ \\
\hline $10^{3}$ & 28 & $>33$ & $>33$ & 27.7 & 33 & $>33$ & 30.3 & 33 & $>33$ & 32.4 & $>33$ & $>33$ \\
\hline
\end{tabular}

a $\mathrm{PCR}=$ direct real-time polymerase chain reaction.

${ }^{\mathrm{b}}$ Cell concentration. For IMS, appropriate amounts of $R$. solanacearum UW551 cells were added to $0.9 \mathrm{ml}$ of indicated extract solution followed by addition of $0.1 \mathrm{ml}$ of $10 \times$ phosphate-buffered saline containing $0.5 \%$ bovine serum albumin (PBSB) and IMS beads. Samples for MCH were prepared in the same manner, except $20 \mu \mathrm{l}$ of $10 \times$ Tris-EDTA was added instead of $10 \times \mathrm{PBSB}$ and then heated for $7 \mathrm{~min}$ at $97^{\circ} \mathrm{C}$ before beads were added. Potato extract samples were 7\% while geranium and soil samples were 3\%. All samples with cells and soil extract were filtered through a 5- $\mu \mathrm{m}$ Versapore filter (Pall Life Sciences number 4489T) before beads were added. Processing on the magnetic particle collector was as before, except beads from all reactions with geranium or soil extracts were washed six instead of three times. Ct values are average of more than three independent experiments; Ct values varied by $<7 \%$ between experiments. Ct values $>33$ are not considered positive for detection because Ct values of 34 to 38 were sometimes obtained with samples lacking cells or DNA. 
with $R$. solanacearum-specific oligonucleotides to several other standard methods to reduce the effect of PCR inhibitors in total DNA prepared from complex samples prior to detection by nested PCR with $R$. solanacearum-specific primers. In general, their $\mathrm{MCH}$ did not perform as well as the other methods when applied to soil or to tissue samples from five different plants, including tomato and geranium. Nonetheless, both $\mathrm{MCH}$ and the QIAamp kit allowed detection of the pathogen in various soil suspensions down

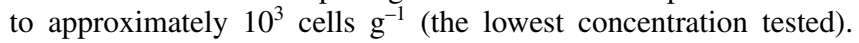
Our $\mathrm{MCH}$ procedure displayed as good as or better sensitivity thresholds and performance when applied to plant and soil extract samples. Additionally, our MCH-coupled RT-PCR is highly specific and $100 \%$ accurate for $\mathrm{R} 3 \mathrm{Bv} 2$ strains.

Our MCH method gave an approximately 10 -fold increase in detection sensitivity with pure cells in water at $>10^{4}$ cells $\mathrm{ml}^{-1}$ but not at lower concentrations. This is similar to detection enhancements reported for other $\mathrm{MCH}$-based detections of bacteria $(1,21,26)$. The magnitude of the improvement largely depends on the hybridization efficiency of the capture oligonucleotide. In preliminary screening, we tested seven capture oligonucleotides (30 to 65 bases long) targeting four R3Bv2-specific genes (RRSL_1249, RRSL_2402, RRSL_2403, and RRSL_2208) (31). Two capture oligonucleotides gave approximately 10 -fold increases in sensitivity when compared with $\mathrm{Ct}$ values for direct PCR (including the 2403CAPYH oligonucleotide described here), three others gave two- to fourfold increases, and two were no better than direct PCR. Neither the length of the capture oligonucleotides nor their proximity to the R3Bv2-specific target (up to 120 bases distant) correlated with $\mathrm{MCH}$ efficiency (results not shown). We also found that adding 10 -fold more $\mathrm{MCH}$ beads into the reactions or extending hybridization times increased the signal by an additional approximately threefold (results not shown) but the extra cost and time detracted from this approach. Although not tested, use of multiple-capture oligonucleotides targeting both DNA strands in one $\mathrm{MCH}$ reaction might improve detection sensitivity.

In conclusion, we demonstrated the applicability and potential of IMS and MCH followed by RT-PCR for reliable detection of R3Bv2 in a variety of samples that mimic those expected to be encountered in field situations. These methods are amenable to adaptation to many venues from remote field locations to highthroughput diagnostic laboratories and now can be evaluated by additional field trials. Overall, IMS-coupled RT-PCR displayed lower $\mathrm{Ct}$ values than MCH-coupled RT-PCR. However, the sensitivity of MCH should be adequate if IMS reagents are unavailable. In addition, when quarantine regulations preclude shipping or handling samples potentially containing live R3Bv2 cells, they can be heat-treated to kill the pathogen before shipment. Obviously, neither MCH nor IMS when followed by RT-PCR will be applicable in cases where isolation of R3Bv2 in pure culture is required for legal reasons prior to enacting official quarantine-mandated countermeasures. Additional research in locations were R3Bv2 is endemic will be required to determine whether these methods are sufficiently reliable to identify samples that deserve more rigorous examination using methods that recover viable cells.

\section{Acknowledgments}

This research was funded by the United States Department of Agriculture Cooperative State Research, Education and Extension Service Integrated Grant number 2007-55605-17843 under Animal and Plant Health Inspection Permit for Select Agents. We thank R. Walcott for advice and assistance in developing $\mathrm{MCH}$ and $\mathrm{L}$. Lipscomb for reading and providing comments on the manuscript.

\section{Literature Cited}

1. Amagliani, G., Omiccioli, E., del Campo, A., Bruce, I. J., Brandi, G., and Magnani, M. 2006. Development of a magnetic capture hybridization-PCR assay for Listeria monocytogenes direct detection in milk samples. J. Appl. Microbiol. 100:375-383.

2. Bates, J. A., Taylor, E. J. A., Kenyon, D. M., and Thomas, J. E. 2001. The application of real-time PCR to the identification, detection and quantification of Pyrenophora species in barley seed. Mol. Plant Pathol. 2:49-57.

3. Boudazin, G., Le Roux, A. C., Josi, K., Labarre, P., and Jouan, B. 1999. Design of division specific primers of Ralstonia solanacearum and applica- tion to the identification of European isolates. Eur. J. Plant Pathol. 105:373380 .

4. Caruso, P., Bertolini, E., Cambra, M., and Lopez, M. M. 2003. A new and sensitive co-operational polymerase chain reaction for rapid detection of Ralstonia solanacearum in water. J. Microbiol. Methods 55:257-272.

5. Cellier, G., and Prior, P. 2010. Deciphering phenotypic diversity of Ralstonia solanacearum strains pathogenic to potato. Phytopathology 100:12501261.

6. Champoiseau, P. G., Jones, J. B., and Allen, C. 2009. Ralstonia solanacearum race 3 biovar 2 causes tropical losses and temperate anxieties. Plant Health Progress. Online publication. doi:10.1094/PHP-2009-0313-01-RV.

7. Chen, J. R., Johnson, R., and Griffiths, M. 1998. Detection of verotoxigenic Escherichia coli by magnetic capture hybridization PCR. Appl. Environ. Microbiol. 64:147-152.

8. Chen, Y., Zhang, W. Z., Liu, X., Ma, Z. H., Li, B., Allen, C., and Guo, J. H. 2010. A real-time PCR assay for the quantitative detection of Ralstonia solanacearum in horticultural soil and plant tissues. J. Microbiol. Biotechnol. 20:193-201.

9. Denny, T. P. 2006. Plant pathogenic Ralstonia species. Pages 573-644 in: Plant-Associated Bacteria. S. S. Gnanamanickam, ed. Springer, Dordrecht, The Netherlands.

10. Denny, T. P., and Hayward, A. C. 2001. Ralstonia. Pages 165-189 in: Laboratory Guide for Identification of Plant Pathogenic Bacteria, 3rd ed. N. W. Schaad, J. B. Jones, and W. Chun, eds. American Phytopathological Society, St. Paul, MN.

11. Denny, T. P., Makini, F. W., and Brumbley, S. M. 1988. Characterization of Pseudomonas solanacearum Tn5 mutants deficient in extracellular polysaccharide. Mol. Plant-Microbe Interact. 1:215-223.

12. Dittapongpitch, V., and Surat, S. 2003. Detection of Ralstonia solanacearum in soil and weeds from commercial tomato fields using immunocapture and the polymerase chain reaction. J. Phytopathol. 151:239-246.

13. Elphinstone, J. G. 1996. Survival and possibilities for extinction of Pseudomonas solanacearum (Smith) Smith in cool climates. Potato Res. 39:403410.

14. Elphinstone, J. G. 2005. The current bacterial wilt situation: a global view. Pages 9-28 in: Bacterial Wilt Disease and the Ralstonia solanacearum Species Complex. C. Allen, P. Prior, and A. C. Hayward, eds. American Phytopathological Society, St. Paul, MN.

15. Elphinstone, J. G., Hennessy, J., Wilson, J. K., and Stead, D. E. 1996. Sensitivity of different methods for the detection of Pseudomonas solanacearum in potato tuber extracts. Bull. OEPP/EPPO Bull. 26:663-678.

16. Espy, M. J., Uhl, J. R., Sloan, L. A., Buckwalter, S. P., Jones, M. F., Vetter, E. A., Yao, J. D. C., Wengenack, N. L., Rosenblatt, J. E., Cockerill, F. R., and Smith, T. F. 2006. Real-time PCR in clinical microbiology: applications for routine laboratory testing. Clin. Microbiol. Rev. 19:165-256.

17. Expert, J. M., Noublanche, F., Poliakoff, F., and Caffier, D. 2000. Evaluation of magnetic capture for detection of Ralstonia solanacearum in various substrates. Bull. OEPP/EPPO Bull. 30:385-389.

18. Fegan, M., Holoway, G., Hayward, A. C., and Timmis, J. 1998. Development of a diagnostic test based on the polymerase chain reaction (PCR) to identify stains of $R$. solanacearum exhibiting the biovar 2 genotype. Pages 34-43 in: Bacterial Wilt Disease: Molecular and Ecological Aspects. P. Prior, C. Allen, and J. Elphinstone, eds. Springer-Verlag, Berlin.

19. Fegan, M., and Prior, P. 2005. How complex is the Ralstonia solanacearum species complex? Pages 449-461 in: Bacterial Wilt Disease and the Ralstonia solanacearum Species Complex. C. Allen, P. Prior, and A. C. Hayward, eds. American Phytopathological Society, St. Paul, MN.

20. Gabriel, D. W., Allen, C., Schell, M. A., Denny, T. P., Greenberg, J. T., Duan, Y. P., Flores-Cruz, Z., Huang, Q., Clifford, J. M., Presting, G., González, E. T., Reddy, J., Elphinstone, J., Swanson, J., Yao, J., Mulholland, V., Liu, L., Farmerie, W., Patnaikuni, M., Balogh, B., Norman, D., Alvarez, A., Castillo, J. A., Jones, J., Saddler, G., Walunas, T., Zhukov, A., and Mikhailova, N. 2006. Identification of open reading frames unique to a Select Agent: Ralstonia solanacearum race 3 biovar 2. Mol. Plant-Microbe Interact. 19:69-79.

21. Ha, Y., Fessehaie, A., Ling, K. S., Wechter, W. P., Keinath, A. P., and Walcott, R. R. 2009. Simultaneous detection of Acidovorax avenae subsp. citrulli and Didymella bryoniae in cucurbit seedlots using magnetic capture hybridization and real-time polymerase chain reaction. Phytopathology 99:666-678.

22. Hayward, A. C. 1991. Biology and epidemiology of bacterial wilt caused by Pseudomonas solanacearum. Annu. Rev. Phytopathol. 29:65-87.

23. Hayward, C. 1996. Molecular biology in systematics and diagnosis of phytopathogenic prokaryotes. Phytoparasitica 24:271-275.

24. Hong, J. C., Momol, M. T., Jones, J. B., Ji, P. S., Olson, S. M., Allen, C., Perez, A., Pradhanang, P., and Guven, K. 2008. Detection of Ralstonia solanacearum in irrigation ponds and aquatic weeds associated with the ponds in north Florida. Plant Dis. 92:1674-1682.

25. Huang, J., Wu, J., Li, C., Xiao, C., and Wang, G. 2009. Specific and sensitive detection of Ralstonia solanacearum in soil with quantitative, real-time PCR assays. J. Appl. Microbiol. 107:1729-1739.

26. Jacobsen, C. S. 1995. Microscale detection of specific bacterial-DNA in soil with a magnetic capture-hybridization and PCR amplification assay. Appl. Environ. Microbiol. 61:3347-3352. 
27. Janse, J. D. 1996. Potato brown rot in western Europe-history, present occurrence and some remarks on possible origin, epidemiology and control strategies. Bull. OEPP/EPPO Bull. 26:679-695.

28. Janse, J. D., van den Beld, H. E., Elphinstone, J., Simpkins, S., Tjou-TamSin, N. N. A., and van Vaerenbergh, J. 2004. Introduction to Europe of Ralstonia solanacearum biovar 2, race 3 in Pelargonium zonale cuttings. J. Plant Pathol. 87:147-155.

29. Kang, Y., Saile, E., Schell, M. A., and Denny, T. P. 1999. Quantitative immunofluorescence of regulated eps gene expression in single cells of Ralstonia solanacearum. Appl. Environ. Microbiol. 65:2356-2362.

30. Kreader, C. A. 1996. Relief of amplification inhibition in PCR with bovine serum albumin or T4 gene 32 protein. Appl. Environ. Microbiol. 62:11021106.

31. Kubota, R., Schell, M. A., Peckham, G. D., Rue, J., Alvarez, A. M., Allen, C., and Jenkins, D. M. 2011. In silico genomic subtraction guides development of highly accurate DNA-based diagnostics for Ralstonia solanacearum race 3 biovar 2 and blood disease bacterium. J. Gen. Plant Pathol. 77:182-193.

32. Lambert, C. D. 2002. Agricultural Bioterrorism Protection Act of 2002: Possession, Use, and Transfer of Biological; Agents and Toxins; Interim and Final Rule. (7 CFR Part 331). Federal Register 67:76908-76938.

33. Leite, R. P., Jones, J. B., Somodi, G. C., Minsavage, G. V., and Stall, R. E. 1995. Detection of Xanthomonas campestris pv. vesicatoria associated with pepper and tomato seed by DNA amplification. Plant Dis. 79:917-922.

34. Liu, H., Kang, Y., Genin, S., Schell, M. A., and Denny, T. P. 2001. Twitching motility of Ralstonia solanacearum requires a type IV pilus system. Microbiology 147:3215-3229.

35. McGregor, D. P., Forster, S., Steven, J., Adair, J., Leary, S. E. C., Leslie, D. L., Harris, W. J., and Titball, R. W. 1996. Simultaneous detection of microorganisms in soil suspension based on PCR amplification of bacterial 16S rRNA fragments. BioTechniques 21:463-471.

36. Milling, A., Babujee, L., and Allen, C. 2011. Ralstonia solanacearum extracellular polysaccharide is a specific elicitor of defense responses in wiltresistant tomato plants. PLoS One 6(1):e15853. Online publication. doi:10.1371/journal.pone.0015853.

37. Milling, A., Meng, F. H., Denny, T. P., and Allen, C. 2009. Interactions with hosts at cool temperatures, not cold tolerance, explain the unique epidemiology of Ralstonia solanacearum race 3 biovar 2. Phytopathology 99:1127-1134

38. Minsavage, G. V., Thompson, C. M., Hopkins, D. L., Leite, R. M. V. B., and Stall, R. E. 1994. Development of a polymerase chain reaction protocol for detection of Xylella fastidiosa in plant tissue. Phytopathology 84:456-461.

39. Opina, N., Tavner, F., Hollway, G., Wang, J.-F., Li, T. H., Maghirang, R., Fegan, M., Hayward, A. C., Krishnapillai, V., Hong, W. F., Holloway, B. W., and Timmis, J. N. 1997. A novel method for development of species and strain-specific DNA probes and PCR primers for identifying Burkholderia solanacearum (formerly Pseudomonas solanacearum). Asia-Pac. J. Mol. Biol. Biotech. 5:19-30.

40. Ozakman, M., and Schaad, N. W. 2003. A real-time BIO-PCR assay for detection of Ralstonia solanacearum race 3, biovar 2, in asymptomatic potato tubers. Can. J. Plant Pathol. 25:232-239.

41. Pastrik, K.-H., Elphinstone, J. G., and Pukall, R. 2002. Sequence analysis and detection of Ralstonia solanacearum by multiplex PCR amplification of $16 \mathrm{~S}-23 \mathrm{~S}$ ribosomal intergenic spacer region with internal positive control. Eur. J. Plant Pathol. 108:831-842.

42. Picard, C., Ponsonnet, C., Paget, E., Nesme, X., and Simonet, P. 1992. Detection and enumeration of bacteria in soil by direct DNA extraction and polymerase chain reaction. Appl. Environ. Microbiol. 58:2717-2722.

43. Poussier, S., Cheron, J. J., Couteau, A., and Luisetti, J. 2002. Evaluation of procedures for reliable PCR detection of Ralstonia solanacearum in common natural substrates. J. Microbiol. Methods 51:349-359.

44. Poussier, S., and Luisetti, J. 2000. Specific detection of biovars of Ralstonia solanacearum in plant tissues by nested-PCR-RFLP. J. Plant Pathol. 106:255-265

45. Pradhanang, P. M., Elphinstone, J. G., and Fox, R. T. V. 2000. Sensitive detection of Ralstonia solanacearum in soil: A comparison of different detection techniques. Plant Pathol. 49:414-422.

46. Priou, S., Gutarra, L., and Aley, P. 2006. An improved enrichment broth for the highly sensitive and reliable detection of Ralstonia solanacearum (biovar 1 and 2A) in soil using double-antibody sandwich enzyme-linked immunosorbent assay. Plant Pathol. 55:36-45.

47. Purdy, K. J. 2005. Nucleic acid recovery from complex environmental samples. Methods Enzymol. 397:271-292.

48. Robinson-Smith, A., Elphinstone, J. G., and Forde, S. M. D. O. 1995 Production of antibodies to Pseudomonas solanacearum, the causative agent of bacterial wilt. Food Agric. Immunol. 7:67-79.

49. Salanoubat, M., Genin, S., Artiguenave, F., Gouzy, J., Mangenot, S., Arlat M., Billault, A., Brottier, P., Camus, J. C., Cattolico, L., Chandler, M., Choisne, N., Claudel-Renard, C., Cunnac, S., Demange, N., Gaspin, C., Lavie, M., Moisan, A., Robert, C., Saurin, W., Thébault, P., Schiex, T., Siguier, P., Whalen, M., Wincker, P., Levy, M., Weissenbach, J., and Boucher, C. A. 2002. The genome sequence of the wide host-range plant pathogen Ralstonia solanacearum. Nature 415:497-502.

50. Schell, M. A. 2000. Control of virulence and pathogenicity genes of Ralstonia solanacearum by an elaborate sensory array. Annu. Rev. Phytopathol. 38:263-292.

51. Schönfeld, J., Heuer, H., van Elsas, J. D., and Smalla, K. 2003. Specific and sensitive detection of Ralstonia solanacearum in soil on the basis of PCR amplification of fliC fragments. Appl. Environ. Microbiol. 69:7248-7256.

52. Swanson, J. K., Montes, L., Mejia, L., and Allen, C. 2007. Detection of latent infections of Ralstonia solanacearum race 3 biovar 2 in geranium. Plant Dis. 91:828-834.

53. Swanson, J. K., Yao, J., Tans-Kersten, J., and Allen, C. 2005. Behavior of Ralstonia solanacearum race 3 biovar 2 during latent and active infection of geranium. Phytopathology 95:136-143.

54. Thammakijjawat, P., Thaveechai, N., Kositratana, W., Chunwongse, J., Frederick, R. D., and Schaad, N. W. 2006. Detection of Ralstonia solanacearum in ginger rhizomes by real-time PCR. Can. J. Plant Pathol. 28:391-400

55. van Elsas, J. D., Kastelein, P., de Vries, P. M., and van Overbeek, L. S. 2001. Effects of ecological factors on the survival and physiology of Ralstonia solanacearum bv. 2 in irrigation water. Can. J. Microbiol. 47:842-854.

56. Villa, J. E., Tsuchiya, K., Horita, M., Opina, N., and Hyakumachi, M. 2005. Phylogenetic relationships of Ralstonia solanacearum species complex strains from Asia and other continents based on 16S rDNA, endoglucanase, and $h r p B$ gene sequences. J. Gen. Plant Pathol. 71:39-46.

57. Walcott, R. R., and Gitaitis, R. D. 2000. Detection of Acidovorax avenae subsp. citrulli in watermelon seed using immunomagnetic separation and the polymerase chain reaction. Plant Dis. 84:470-474.

58. Watson, R. J., and Blackwell, B. 2000. Purification and characterization of a common soil component which inhibits the polymerase chain reaction. Can. J. Microbiol. 46:633-642.

59. Weller, S. A., Elphinstone, J. G., Smith, N. C., Boonham, N., and Stead, D. E. 2000. Detection of Ralstonia solanacearum strains with a quantitative, multiplex, real-time, fluorogenic PCR (TaqMan) assay. Appl. Environ. Microbiol. 66:2853-2858.

60. Weller, S. A., Elphinstone, J. G., Smith, N. C., and Stead, D. E. 2000. Detection of Ralstonia solanacearum from potato tissue by post-enrichment TaqMan PCR. Bull. OEPP/EPPO Bull. 30:381-383.

61. Williamson, L., Nakaho, K., Hudelson, B., and Allen, C. 2002. Ralstonia solanacearum race 3, biovar 2 strains isolated from geranium are pathogenic on potato. Plant Dis. 86:987-991.

62. Wilson, I. G. 1997. Inhibition and facilitation of nucleic acid amplification Appl. Environ. Microbiol. 63:3741-3751.

63. Wullings, B. A., van Beuningen, A. R., Janse, J. D., and Akkermans, A. D. L. 1998. Detection of Ralstonia solanacearum, which causes brown rot of potato, by fluorescent in situ hybridization with $23 \mathrm{~S}$ rRNA-targeted probes. Appl. Environ. Microbiol. 64:4546-4554.

64. Yan, G. P., Smiley, R. W., Okubara, P. A., Skantar, A., Easley, S. A., Sheedy, J. G., and Thompson, A. L. 2008. Detection and discrimination of Pratylenchus neglectus and $P$. thorne $i$ in DNA extracts from soil. Plant Dis. 92:1480 1487. 